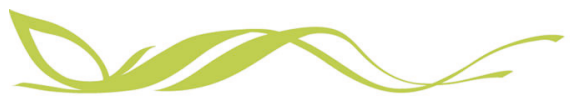

COMMUNICATIONS

EARTH\&ENMRONMENT

ARTICLE

\author{
https://doi.org/10.1038/s43247-020-00040-3 OPEN
}

\title{
Fracture dolomite as an archive of continental palaeo-environmental conditions
}

Andre Baldermann (10 ${ }^{1 凶}$, Florian Mittermayr ${ }^{2}$, Stefano M. Bernasconi (D) ${ }^{3}$, Martin Dietzel (1) ${ }^{1}$, Cyrill Grengg ${ }^{1}$, Dorothee Hippler (10) ${ }^{1}$, Tobias Kluge ${ }^{4}$, Albrecht Leis (10) ${ }^{5}$, Ke Lin ${ }^{6}$, Xianfeng Wang (1) ${ }^{6}$, Andrea Zünterl ${ }^{1,7} \&$ Ronny Boch ${ }^{1,7}$

The origin of Quaternary dolomites in continental environments (e.g. karst and lakes) is barely constrained compared to marine dolomites in sedimentary records. Here we present a study of dolomite and aragonite formations infilling young fractures of the 'Erzberg' iron ore deposit, Austria, under continental-meteoric and low temperature conditions. Two dolomite generations formed shortly after the Last Glacial Maximum ( $20 \mathrm{kyr} B P)$ : dolomite spheroids and matrix dolomite. Clumped isotope measurements and $\mathrm{U} / \mathrm{Th}$ disequilibrium ages reveal formation temperatures of $0-3^{\circ} \mathrm{C}\left( \pm 6^{\circ} \mathrm{C}\right)$ and $3-20^{\circ} \mathrm{C}\left( \pm 5^{\circ} \mathrm{C}\right)$ for the both dolomite types, and depositional ages around $19.21 \pm 0.10 \mathrm{kyr} B P$ and $13.97 \pm 0.08 \mathrm{kyr}$ BP or younger, respectively. Meteoric solution and carbonate isotope compositions $\left(\delta^{18} \mathrm{O}, \delta^{13} \mathrm{C}\right.$ and ${ }^{87} \mathrm{Sr} / 86 \mathrm{Sr}$ ) indicate the dolomites formed via aragonite and high-Mg calcite precursors from $\mathrm{CO}_{2}$-degassed, $\mathrm{Mg}$-rich solutions. Our study introduces low temperature dolomite formations and their application as a sedimentary-chemical archive.

\footnotetext{
${ }^{1}$ Institute of Applied Geosciences \& NAWI Graz Geocenter, Graz University of Technology, Rechbauerstrasse 12, 8010 Graz, Austria. ${ }^{2}$ Institute of Technology and Testing of Building Materials, Graz University of Technology, Inffeldgasse 24, 8010 Graz, Austria. ${ }^{3}$ Geological Institute, ETH Zurich, Sonneggstrasse 5, 8092 Zürich, Switzerland. ${ }^{4}$ Institute of Environmental Physics, Heidelberg University, Im Neuenheimer Feld 229,69120 Heidelberg, Germany. ${ }^{5}$ JR-AquaConSol GmbH, Steyrergasse 21, $8010 \mathrm{Graz}$, Austria. ${ }^{6}$ Earth Observatory of Singapore and Asian School of the Environment, Nanyang Technological University, 50 Nanyang Avenue, 639798 Singapore City, Singapore. ${ }^{7}$ Geoconsult ZT GmbH, Team Geochemistry \& Monitoring, Hölzlstraße 5, 5071 Wals, Salzburg, Austria. ${ }^{\circledR}$ email: baldermann@tugraz.at
} 
F actors that control the origin and distribution of sedimentary dolomite in geologic records are intensely debated in the literature due to the much higher abundance of dolomites in ancient sedimentary rocks ${ }^{1-4}$, compared to modern marine and continental sediments ${ }^{5,6}$. This enigma is referred to as the "dolomite problem"7-10. Numerous mechanisms and models to explain the kinetic constraints on low-temperature dolomite formation in nature have been postulated, with the recognition of mineralogical, hydrogeochemical, and microbiological factors ${ }^{11-15}$.

Modern dolomite-forming environments are mainly marine associated, such as sabkha flats, methane seeps, playa lakes and hypersaline lagoons, where elevated water temperatures (up to $\sim 60^{\circ} \mathrm{C}$ ), high $\mathrm{Mg} / \mathrm{Ca}$ ratios and carbonate alkalinity as well as the presence of reactive templates (e.g., nuclei or seeds), sulfatereducing bacteria and extracellular polymeric substances (EPS) secreted by microorganisms have been reasonably suggested to promote and accelerate dolomitization $3,6,16-19$. Occurrences of modern and ancient sedimentary dolomites have also been observed in "exotic" continental surroundings, such as in speleothems ${ }^{20}$, in palustrine-pedogenic sediments ${ }^{21,22}$, in ephemeral wetlands ${ }^{23}$ and in dolomitic lakes ${ }^{24,25}$, where dolomite frequently precipitates at low to ambient temperature $\left(\sim 4{ }^{\circ} \mathrm{C}\right.$ to $\left.35^{\circ} \mathrm{C}\right)$. These continental dolomites are often interpreted to have been formed under the influence of micro- or macrobiota, but without the direct control of physicochemical conditions archetypically thought to facilitate dolomite precipitation, such as high $\mathrm{Mg} / \mathrm{Ca}$ ratios, elevated alkalinity and temperature ${ }^{26}$. However, details on the nature, timing and processes governing the formation of continental dolomite at low temperature remain largely elusive and analytical evidence of the proposed cool formation temperatures, for example by clumped isotope thermometry ${ }^{27-29}$, is often missing.

Here, we present a case study of dolomite and prominent $\mathrm{CaCO}_{3}$ precipitates (i.e., laminated successions of aragonite and minor calcite; the so-called "erzbergite" 30 ) infilling young vertical fractures within the Erzberg iron ore deposit, Eastern Alps, Austria (Fig. 1). This locality hosts the largest siderite $\left[\mathrm{FeCO}_{3}\right]$ deposit worldwide ${ }^{31}$. Herein, carbonate-based U/Th ages, formation temperatures derived from clumped isotope $\left(\Delta_{47}\right)$ measurements and high-resolution chemical, petrographic and isotope $\left(\delta^{13} \mathrm{C}, \delta^{18} \mathrm{O}\right.$ and $\left.{ }^{87} \mathrm{Sr} /{ }^{86} \mathrm{Sr}\right)$ records of authigenic dolomite and erzbergite fracture mineralizations were investigated. Local host rocks and modern meteoric water, collected from different sections of the open pit mine, were also assessed to constrain the nature, timing and driving factors of dolomite formation in a continental-meteoric setting at low temperature. Our results reveal a complex evolutionary history of the dolomite and erzbergite fracture mineralizations as well as the potential of these continental carbonate archives to be used in palaeoenvironmental and palaeo-climate studies, complementary to the widespread modern and ancient carbonate deposits of the marine realm.

\section{Results}

Occurrence of authigenic dolomite and erzbergite in young fractures. The sedimentary and tectonic evolution of the Erzberg iron ore deposit is marked by Variscan age nappe stacking of Silurian and Carboniferous siliceous shales sandwiching lower Devonian limestones, which host the main iron ore body (Fig. 1c). Discordant Permo-Triassic transgressive sedimentary rocks and Late Cretaceous Alpine deformation follow this sequence $^{32}$. The sedimentary succession is cross-cut by numerous vertical fractures of variable width (few centimetres to several decimeters) and length (tens of meters) (Figs. 1d and 2a) that are interpreted to have been developed during fault tectonics or gravitational mass movements up to the Late Pleistocene ${ }^{30}$. These fractures are partly healed with authigenic erzbergite and more rarely dolomite, especially in the southern part of the Erzberg, e.g., encountered on the pit level "Schuchart" (Fig. 2a-c). The young U/Th ages of the erzbergite $(19.21 \pm 0.10$ to $13.11 \pm$ 0.09 kyr BP, see Supplementary Table 1) indicate the healing of the fractures by carbonate precipitation started after the Last Glacial Maximum ( 20 kyr BP 33 ) onwards (Fig. 2c). The formation of the erzbergite is post-dated by the occurrence of two generations of brecciated dolomite-hosting layers of either dark brown or light beige color (Fig. 2c), which replace the erzbergite and exhibit unique petrographic, mineralogical and isotope chemical signatures.

Mineralogy, geochemistry, and petrography of dolomite fracture mineralizations. The light beige dolomite-hosting layer consists of poorly ordered, calcian dolomite $(79 \pm 6 \mathrm{wt} . \%, 54 \pm$ $1 \mathrm{~mol} \% \mathrm{CaCO}_{3}$, cation ordering ratio of $\left.0.25 \pm 0.06 ; n=6\right)$, erzbergite ( $8 \pm 5$ wt. $\%$ of aragonite), quartz ( $5 \pm 1$ wt.\%), illite (4 \pm 1 wt.\%), Fe-(hydr)oxide grains $(4 \pm 2$ wt.\% of goethite and hematite) and rarely ankerite (see Fig. 3a and Supplementary Fig. 1a for bulk mineralogy). On the contrary, the dark brown dolomite-hosting layer contains more near-stoichiometric and better crystallized dolomite $\left(74 \pm 5\right.$ wt. $\%, 51 \pm 1 \mathrm{~mol} \% \mathrm{CaCO}_{3}$, cation ordering ratio of $0.35 \pm 0.08 ; n=4)$ than the light beige layer. The dark brown dolomite-hosting layer has a similar proportion of quartz $(5 \pm 1 \mathrm{wt} . \%)$ and illite $(4 \pm 2 \mathrm{wt} . \%)$, but a higher content of finely disseminated Fe-(hydr)oxides $(13 \pm 4 \mathrm{wt} . \%)$ and sporadically ankerite clasts, explaining its darker color. Clumped isotope data obtained from the two dolomite-bearing layers, and $\mathrm{U} / \mathrm{Th}$ ages from the adjacent erzbergite deposits (labeled as EB1 to EB3 in Fig. 3a) hosting the dolomite mineralizations, reveal formation temperatures of 3 to $20^{\circ} \mathrm{C}\left( \pm 5^{\circ} \mathrm{C}\right)$ for the light beige colored layer and 0 to $3{ }^{\circ} \mathrm{C}\left( \pm 6^{\circ} \mathrm{C}\right)$ for the dark brown colored layer (see Supplementary Table 2 for carbonate formation temperatures), with depositional ages younger than $13.97 \pm 0.08 \mathrm{kyr}$ $\mathrm{BP}$ and $19.21 \pm 0.10 \mathrm{kyr} \mathrm{BP}$, respectively.

Petrographically, both dolomite-hosting layers contain two types of sedimentary dolomite with distinct abundance, texture, crystal shape and composition. The light beige dolomite-hosting layer is dominated by very fine-grained $(\sim 5-15 \mu \mathrm{m}$ in size), subhedral dolomite rhombs with a composition of $\mathrm{Ca}_{1.00-1.19} \mathrm{Mg}_{0.78-0.99}\left(\mathrm{CO}_{3}\right)_{2}$ (Fig. 3b, d, f, g). This dolomite type (hereafter referred to as matrix dolomite) shows a diffuse contact to fibrous aragonite needles and corroded aragonite relics (Fig. 3d), exhibiting embayments and interpenetrated features, which are typical for a replacement process ${ }^{20}$. The matrix dolomite is characterized by moderate amounts of Fe $(1700 \pm 1400 \mathrm{mg} / \mathrm{kg})$ and $\mathrm{Mn}(400 \pm 600 \mathrm{mg} / \mathrm{kg})$ and low amounts of $\mathrm{Na}(10 \pm 5 \mathrm{mg} / \mathrm{kg})$ and $\mathrm{Sr}(20 \pm 5 \mathrm{mg} / \mathrm{kg})$, on average. Neither a cloudy-center-clearrim texture nor zonation patterns are observable in this dolomite type (see Supplementary Fig. 2 for dolomite composition and microstructural features). Rarely, spheroidal dolomite crystals interwoven with illitic clays are seen, accounting for $<5 \%$ of the total dolomite content, judged from optical microscopy of thick sections. In contrast, the dark brown dolomite-hosting layer appears as a mixture of matrix dolomite growing onto spheroidal dolomite, which presumably corrodes and replaces former acicular aragonite crystals and aragonite fans (Fig. 3c, e). Spheroidal dolomite locally accounts for up to $30 \%$ of the total dolomite content and exhibits, on average, lower concentrations of $\mathrm{Sr}(15 \pm$ $5 \mathrm{mg} / \mathrm{kg})$, similar $\mathrm{Mn}(400 \pm 500 \mathrm{mg} / \mathrm{kg})$ contents and slightly higher Fe $(2500 \pm 1700 \mathrm{mg} / \mathrm{kg})$ and $\mathrm{Na}(15 \pm 5 \mathrm{mg} / \mathrm{kg})$ contents compared to the matrix dolomite. The dolomite spheroids are 


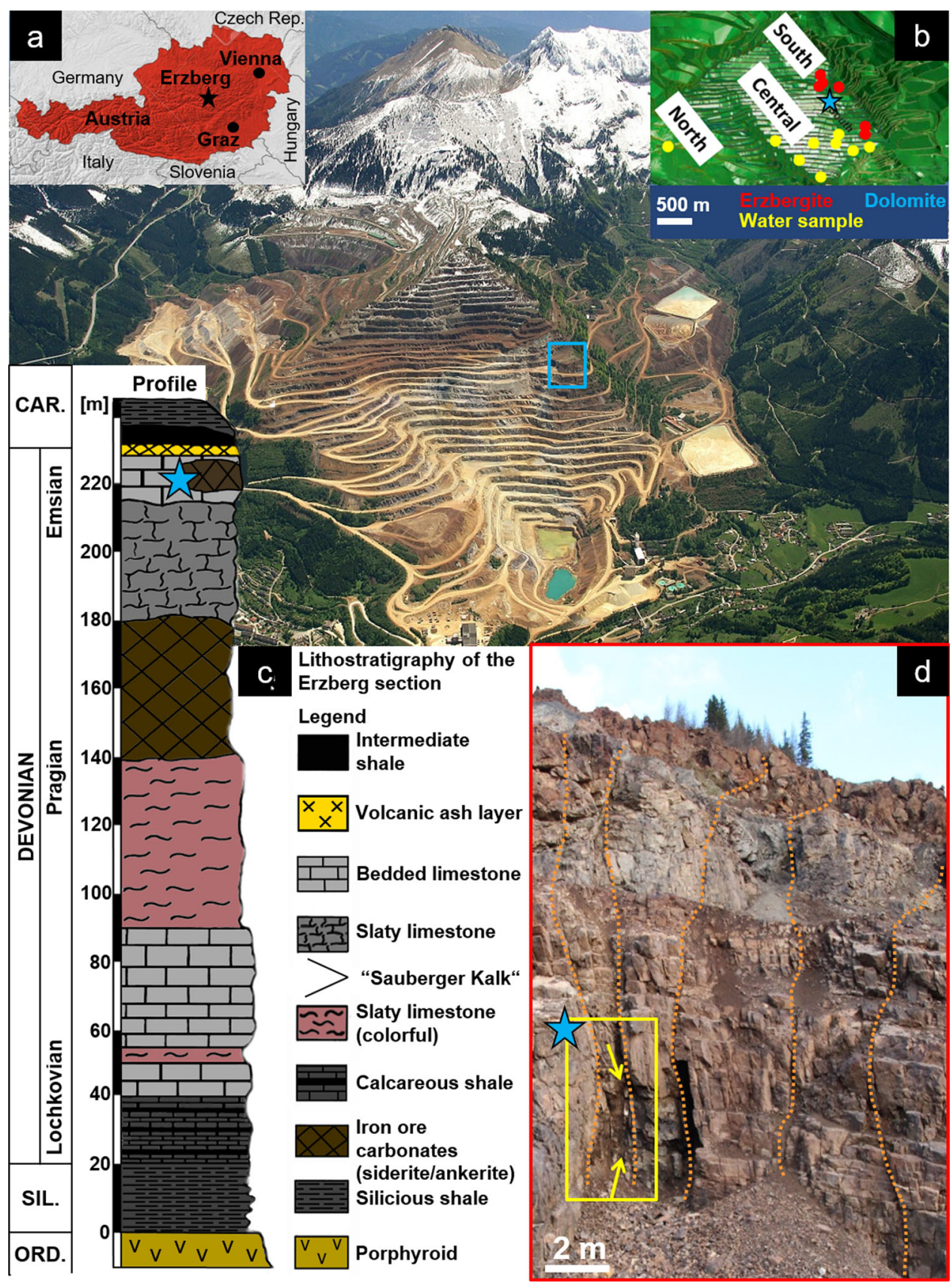

Fig. 1 Appearance of authigenic carbonate fracture mineralizations across the Erzberg (Eastern Alps, Austria). a Aerial overview of the Erzberg open pit iron ore mine, located approximately $90 \mathrm{~km} \mathrm{NW}$ of Graz close to the Northern Calcareous Alps (with permission from Bavaria Luftbild Verlags GmbH). b Digital surface model of the Erzberg showing the positions of sampled carbonate fracture mineralizations (erzbergite and dolomite-hosting layers) and modern aqueous solutions (i.e., fracture water and surface water). c Lithostratigraphic profile of the Erzberg with the location of dolomite-hosting intervals highlighted by the blue star. $\mathbf{d}$ Partly iron ore-bearing and fractured (indicated by the orange dotted lines) ferruginous limestones, the so-called "Sauberger Kalk", hosting the carbonate fracture mineralizations (sample location marked with yellow box and arrows) in the southern part of Erzberg (the position is marked by the blue square in $\mathbf{a}$ ).

$\sim 50-300 \mu \mathrm{m}$ across and typically show a higher Ca content in the inner part and a higher stoichiometry toward the rim, in the range $\mathrm{Ca}_{0.89-1.19} \mathrm{Mg}_{0.80-1.10}\left(\mathrm{CO}_{3}\right)_{2}$ (Fig. 3f, g).

\section{Discussion}

The dolomitization process. Fracture opening, host rock dissolution and prior aragonite precipitation: The host rocks surrounding the main carbonate fracture mineralizations are reddish-brown to light gray ferruginous limestones (the socalled "Sauberger Kalk"), which were deposited during the lower
Devonian (Fig. 1a). These limestones are partially mineralized by iron ore carbonates, such as ankerite $\left[\mathrm{Ca}(\mathrm{Fe}, \mathrm{Mg}, \mathrm{Mn})\left(\mathrm{CO}_{3}\right)_{2}\right]$ and siderite (Fig. 2a and Supplementary Fig. $1 \mathrm{~b}$ for bulk mineralogy), which precipitated from $\mathrm{Fe}^{2+}$-rich hypersaline solutions at temperatures between $200{ }^{\circ} \mathrm{C}$ and $350{ }^{\circ} \mathrm{C}$ in the Late Triassic ${ }^{32,34}$. Owing to this metasomatic overprinting, the ferruginous limestones and the iron ore carbonates are isotopically offset from mean Devonian marine limestones and further display metasomatic-epigenetic structures. The proposed (neo)tectonic activity in the Late Pleistocene (Stage i) in Fig. 4) led to the 

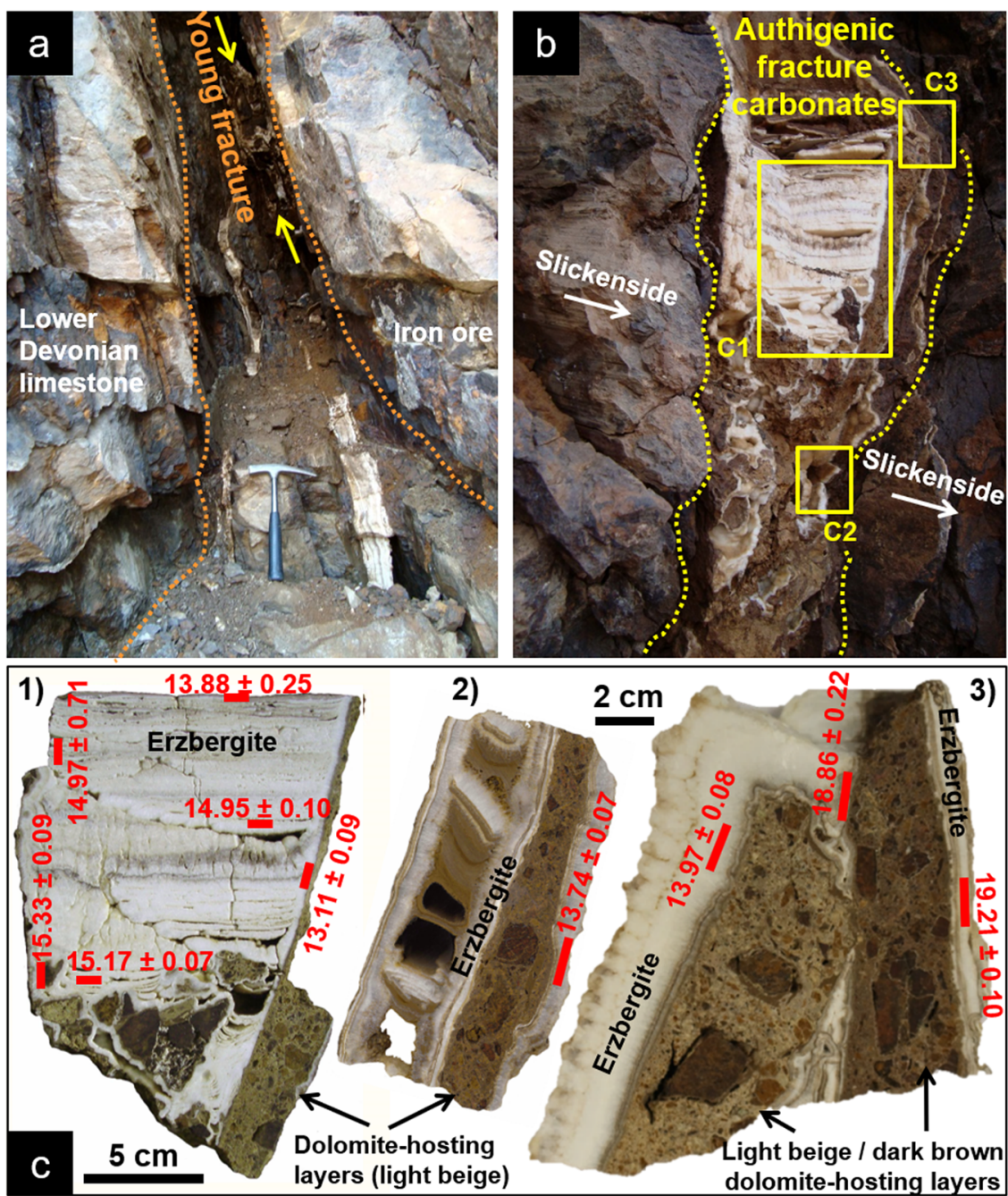

Fig. 2 U/Th-based depositional ages of selected carbonate fracture mineralizations at Erzberg. a The close-up of the image shown in Fig. 1d displays prominent erzbergite and dolomite mineralizations infilling vertical fractures. The local host rocks are represented by lower Devonian limestones (greyish "Sauberger Kalk", left) and darker iron ore carbonates (siderite and ankerite, right), which show abundant slickensides, interpreted to be due to young tectonic or gravitational mass movements at Erzberg30. b Detailed view inside the fracture showing different generations of carbonate fracture mineralizations, e.g., whitish aragonite-dominated erzbergite and brownish dolomite-hosting layers. c U/Th ages of samples C1 to C3 (in kyr BP; position is marked with yellow boxes in b) displaying two generations of authigenic dolomite, either light beige ( 14 kyr BP and younger) or dark brown ( 19 kyr BP) in color.

formation of open fractures. Geologically young vertical fractures at Erzberg provide fresh chemical reaction surfaces and important water flow paths, which promote the infiltration of meteoric water-derived solutions from the adjacent catchment areas. Subsequent fluid-rock interactions cause oxidation of accessory $(\mathrm{Fe}, \mathrm{Cu}, \mathrm{Zn})$-sulfide minerals exposed in the iron ore host rocks and related generation of sulfuric acid, as supported by sulfur isotopic compositions of modern surface and fracture water $(-4.9$ to $+2.5 \%$ of $\delta^{34} \mathrm{SSO}_{4}$, VCDT) and iron sulfides $(-2.2$ to $+5.1 \%$ of $\delta^{34} S_{\text {Pyrite }}, \mathrm{VCDT}$ ) at Erzberg ${ }^{30}$. Sulfuric acid attack facilitates an efficient dissolution of the partly brecciated carbonate host rocks (Stage ii) in Fig. 4), which leads to the mobilization and subsequent enrichment of $\mathrm{Ca}, \mathrm{Mg}$, trace elements ( $\mathrm{Fe}, \mathrm{Sr}, \mathrm{Mn}$ ) and alkalinity along the water flow paths. These processes, coupled with fast outgassing of $\mathrm{CO}_{2}$ in the fissured aquifer (Fig. 5), generate highly differentiated meteoric water-derived solutions with distinct hydrogeochemical signatures (see Supplementary Table 3 for modern water composition) ${ }^{35}$. These include high $\mathrm{Mg} / \mathrm{Ca}$ molar ratios (up to 26) and alkaline conditions ( $\mathrm{pH}$ : 8.1 to 8.8), thus, favorable for the precipitation of the first generations of the erzbergite (EB 1 and 2) shortly after the Last Glacial Maximum (Stage iii) in Fig. 4). Such precipitation of aragonite from meteoric water-derived solutions at very low temperatures is indicated by the clumped isotope data $\left(3 \pm 4^{\circ} \mathrm{C}\right.$ for $\left.\mathrm{EB} 1\right)$, the positive $\delta^{13} \mathrm{C}_{\text {Carb }}$ values due to enhanced $\mathrm{CO}_{2}$ outgassing and isotopically light palaeo-fluid $\delta^{18} \mathrm{O}$ values (inferred from carbonate $\delta^{18} \mathrm{O}$ values and clumped isotope temperatures) in the range of $-11.8 \pm 0.9 \%$ (VSMOW, Supplementary Table 2). These constraints are typical for continental carbonates formed at low temperatures ${ }^{36}$. The formation of aragonite is initially favored over other $\mathrm{Ca}-\mathrm{Mg}$ carbonates, because of the strong kinetic barriers induced by the attachment of partially dehydrated $\mathrm{Mg}^{2+}$ ions onto the surfaces of incipient calcite nuclei ${ }^{37-40}$, inhibiting their growth and favoring the precipitation of aragonite under oxic-vadose conditions, which incorporates virtually no Mg. Prior aragonite precipitation along the water flow path under predominantly open system conditions with respect to gas-solution exchange causes an increase of the aqueous $\mathrm{Mg} / \mathrm{Ca}$ molar ratio downstream, which promotes the precipitation of (very) high Mg-calcite (or an amorphous carbonate precursor) in open 

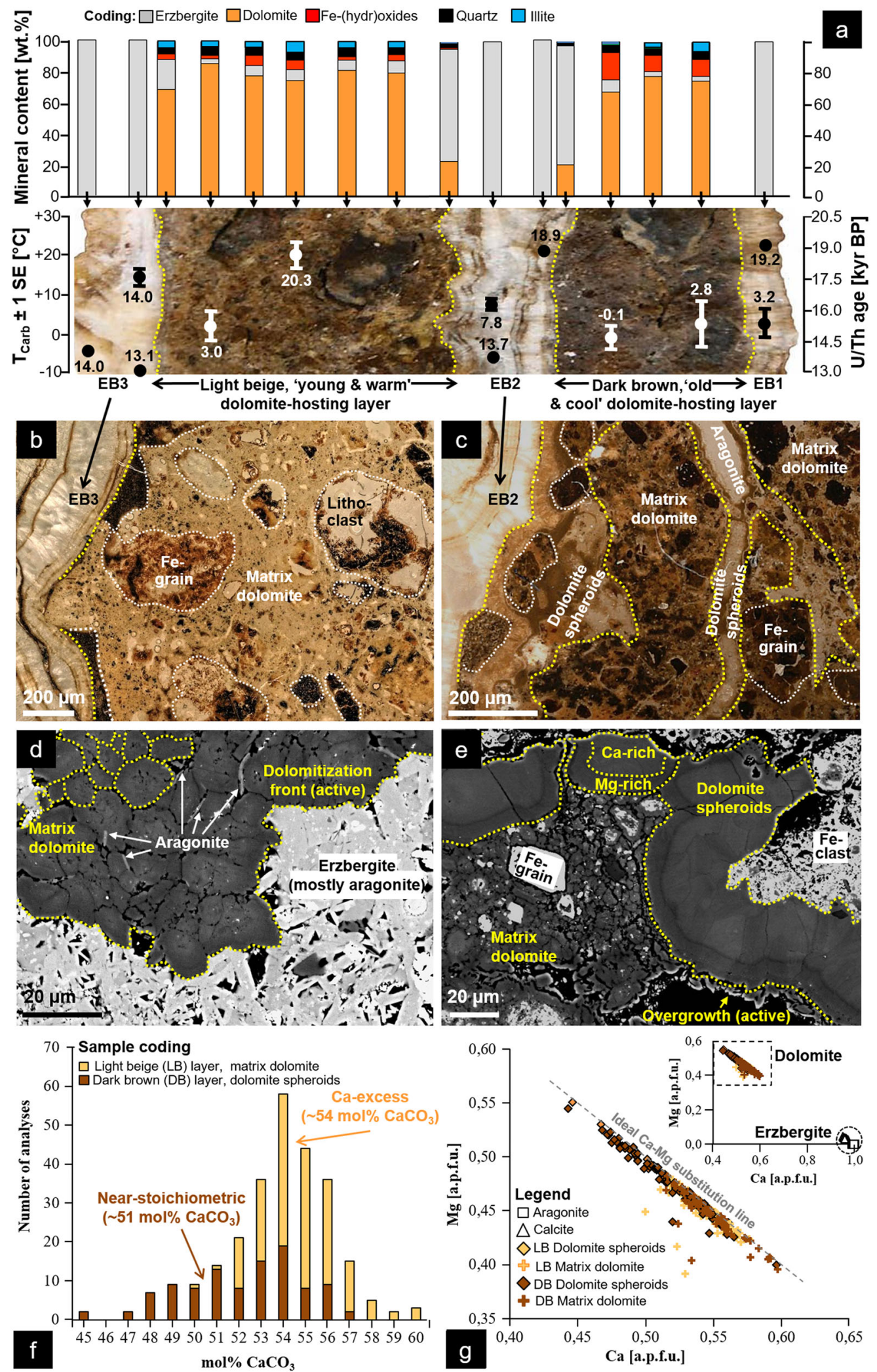

fractures and in the fissured and brecciated host rocks (see Supplementary Fig. 1b for bulk mineralogy), thereby providing the precursors for subsequent transformation to dolomite (see Supplementary Fig. 3 for systematics in carbonate vein mineralizations). Carbonate mineral precipitation under closed system conditions is unlikely, because the high $\delta^{13} \mathrm{C}$ values of the precipitates indicate $\mathrm{CO}_{2}$ degassing and the low $\delta^{18} \mathrm{O}$ values indicate a meteoric water origin. We exclude effects of mineral transition ${ }^{41}$ due to lack of recent hydrothermal activity at Erzberg and experimental evidence against low temperature influence of carbonate mineral transition on clumped isotope signatures ${ }^{42,43}$.

Main dolomitization event(s): The fracture dolomites at Erzberg represent the final product of coupled dissolution and re-precipitation reactions involving metastable aragonite and 
Fig. 3 Compilation of mineralogical, geochemical, and petrographic signatures of the authigenic carbonate fracture mineralizations at Erzberg. a Bulk mineralogy, formation ages and temperatures obtained across subsample C3 (cf. Fig. 2b for sample location; total specimen length: $72 \mathrm{~mm}$ ), based on XRD analyses (analytical error: $<3 \mathrm{wt} . \%$ ), radiometric U/Th age determinations and clumped isotope measurements. The "old and cool" dark brown dolomitehosting layer was formed at $\sim 19 \mathrm{kyr} \mathrm{BP}$ and $0-3^{\circ} \mathrm{C}$, whereas the "young and warm" light beige dolomite-hosting layer started precipitating from $\sim 14 \mathrm{kyr} \mathrm{BP}$ onwards at $3-20^{\circ} \mathrm{C}$. The erzbergite layers EB 1 to EB3 denote white-colored aragonite and minor calcite hosting the two intercalated layers with dominant dolomite. b, c Transmitted-light photomicrographs of polished thick sections showing positions of authigenic dolomite (matrix dolomite and spheroidal dolomite, delimited with yellow dotted lines) and Fe-grains (goethite, hematite and rarely ankerite marked with the white dotted lines) within the light brown versus the dark brown dolomite-hosting layers. d, e Backscattered electron images displaying fine-grained matrix dolomite replacing former aragonite needles and coarse-grained dolomite spheroids with distinct zonation patterns. Dolomitization front propagation within pre-existing aragonite ( \pm high-Mg calcite) and dolomite overgrowth features are abundant, indicative of (sub-)recent dolomite precipitation. $\mathbf{f}$, $\mathbf{g}$ Electron microprobe-based chemical compositions (in atoms per formula unit; a.p.f.u.) of matrix dolomite, dolomite spheroids and erzbergite (insert figure in $\mathbf{g}$ ) showing the "old" dolomite spheroids to be more stoichiometric.

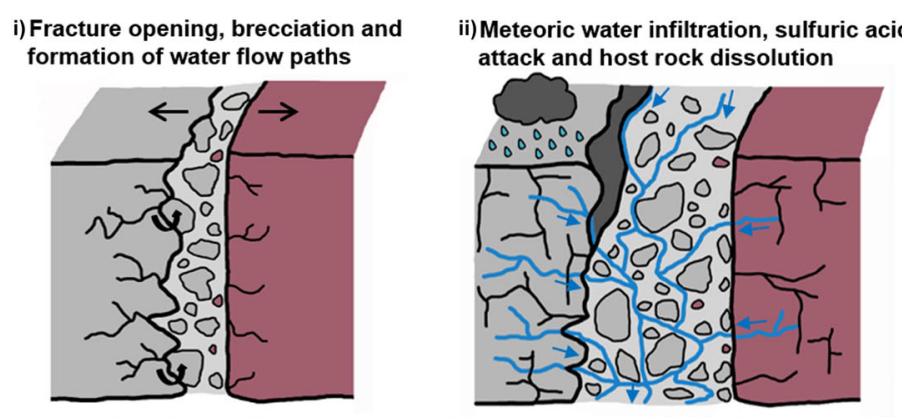

before 19000 years BP (no age control for the initiation period of fault development)

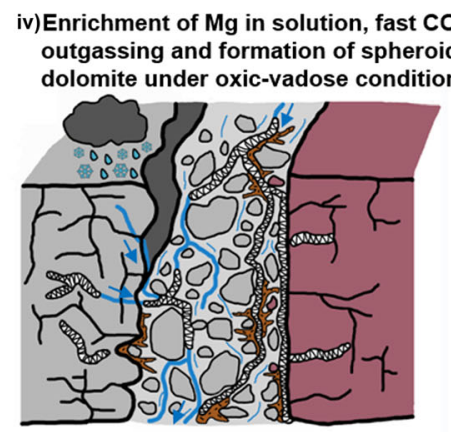

app. 19000 to 14000 years BP v) Secondary erzbergite precipitation, $\mathrm{Mg}$ enrichment and formation of the matrix dolomite under oxic-phreatic conditions

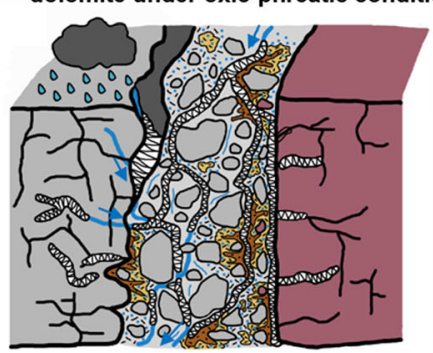

app. 14000 years BP

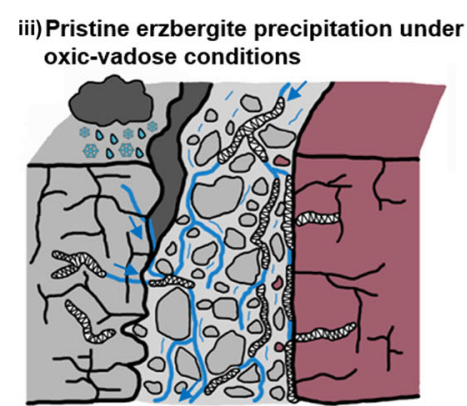

app. 19000 years BP

vi) Development of new $\mathrm{CaCO}_{3}$ vein systems, differentiation of aquifer hydrochemistry and continued dolomite (over)growth

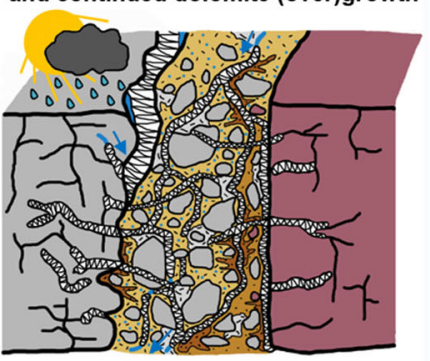

app. 14000 years BP until recently

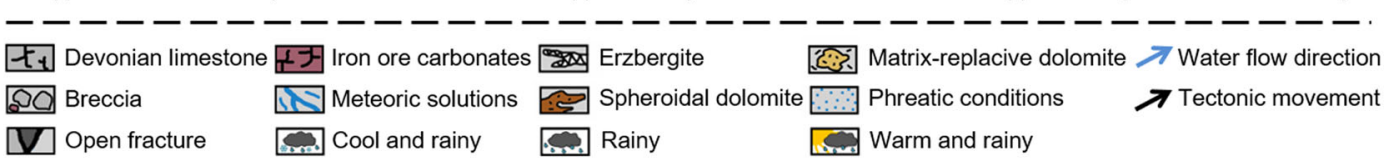

Fig. 4 Schematic model illustrating the evolution of authigenic carbonate fracture mineralizations in the continental-meteoric setting at Erzberg. i-ii Fracture opening and brecciation in the Late Pleistocene promoted the infiltration of meteoric water-derived solutions and subsequent generation of sulfuric acid via oxidation of accessory sulfide minerals causing dissolution of the carbonate host rocks. iii-iv Prevailing prior aragonite precipitation increased the aqueous $\mathrm{Mg} / \mathrm{Ca}$ molar ratio along the water flow path and, coupled with fast outgassing of $\mathrm{CO}_{2}$ in the fissured aquifer, promoted the formation of the dolomite spheroids under oxic-vadose conditions at very low temperatures. $\mathbf{v}$ Warming in the Late Pleistocene caused shifts in the major carbonate precipitation regime, expressed by repeated sequences of aragonite deposition, subsequently transformed into matrix dolomite through laterstage phreatic percolation of aragonite (erzbergite) by Mg-rich water in the fractures at low to ambient temperature. vi The development of young aragonite-calcite vein generations is temporally related to (sub)recent dolomite replacements and overgrowths, consistent with the modern hydrochemistry (strongly increased $\mathrm{Mg} / \mathrm{Ca}$ ratios) at Erzberg.

high-Mg calcite (or amorphous precursor phases), as well as $\mathrm{CO}_{2}$ degassed, meteoric water-derived solutions rich in $\mathrm{Mg}^{43}$. Petrographic analyses of $\mathrm{Ca}-\mathrm{Mg}$ carbonate deposits from modern caves indicate that increased aqueous $\mathrm{Mg} / \mathrm{Ca}$ molar ratios and $\mathrm{CO}_{2}$ outgassing promote sequential carbonate mineral formation, which follows the succession: aragonite, high-Mg calcite, huntite $\left[\mathrm{Mg}_{3} \mathrm{Ca}\left(\mathrm{CO}_{3}\right)_{4}\right]$, disordered dolomite and finally ordered dolomite $^{44}$. This sequence of mineral growth and transformation can also be seen in the carbonate fracture mineralizations at Erzberg, except for huntite, which was not detected: A first generation of "old and cool" dolomite spheroids formed at the expense of aragonite and high-Mg calcite precursors (EB 1 and 2 in Fig. 3a, c) at very low temperatures $\left(0\right.$ to $\left.3 \pm 6^{\circ} \mathrm{C}\right)$ and under vadose conditions (palaeo-fluid $\delta^{18} \mathrm{O}$ : $-14.1 \pm 1.3$ to $-12.7 \pm 1.6 \%$, VSMOW) between $\sim 19.21 \pm 0.10 \mathrm{kyr}$ BP and $13.97 \pm 0.08 \mathrm{kyr}$ BP (Stage iv) in Fig. 4). The establishment of generally warmer temperatures ( 3 to $20 \pm 5^{\circ} \mathrm{C}$ ) and more humid climatic conditions with increased precipitation shortly after the last glaciation caused shifts in the water recharge and flow regime (palaeo-fluid $\delta^{18} \mathrm{O}:-12.9 \pm 1.8$ to $-8.5 \pm 0.9 \%$, VSMOW $)$. This is seen in the 


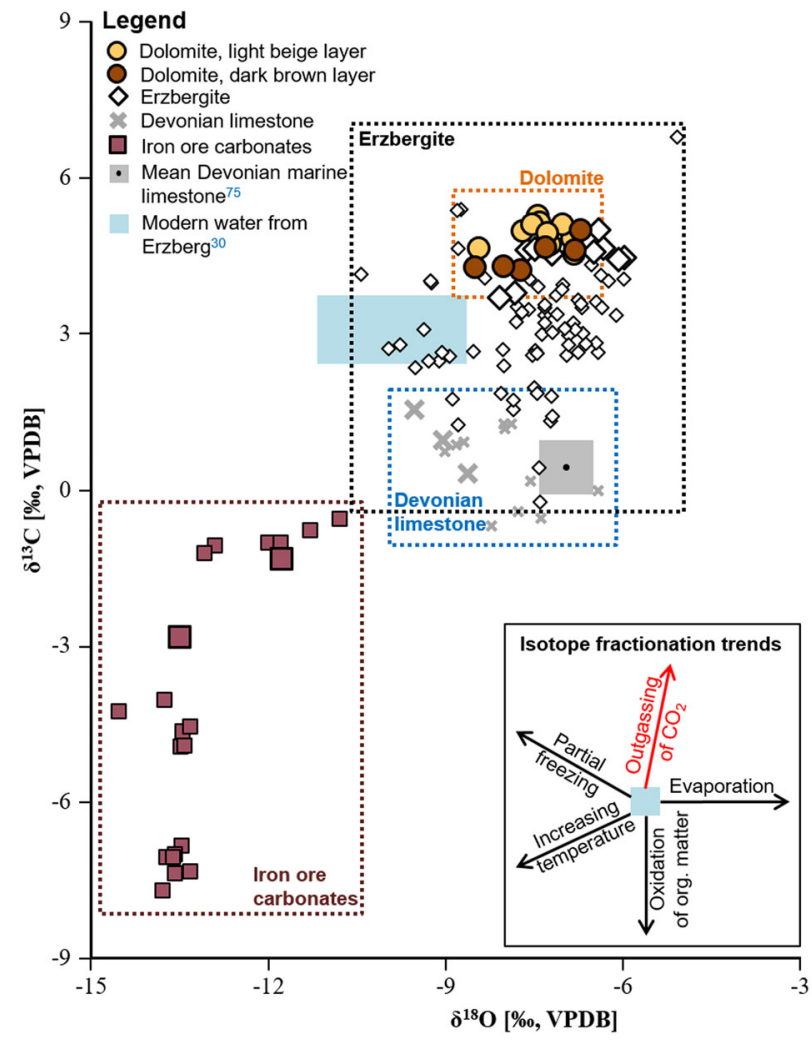

Fig. 5 Stable oxygen vs. carbon isotope composition of modern water, carbonate host rocks, and authigenic carbonate fracture mineralizations at Erzberg. Erzbergite deposits and dolomite-hosting layers represent authigenic carbonate deposits associated with fractures; Devonian limestone and iron ore carbonates (ankerite and siderite) denote local carbonate host rocks. Datasets indicated by the small symbols and same color coding are from taken published literature ${ }^{30}$. The compositions of mean Devonian marine limestones and of modern fracture and surface water from Erzberg are included for comparison. The inserted figure shows typical isotope fractionation trends, i.e., emanating from a parent solution, indicated by the blue square, in isotopic equilibrium with cryogenic carbonates often seen in continental, low temperature environments ${ }^{35}$. Fast outgassing of $\mathrm{CO}_{2}$ at low temperature is a driving factor for carbonate mineral precipitation in fractures at Erzberg.

transition to phreatic conditions ${ }^{45}$, and thus in the carbonate mineral precipitation mode, which is reflected by the formation of younger erzbergite deposits (EB 2 and 3 in Fig. 3a), followed by high-Mg calcite and then "young and warm" matrix-replacive dolomite (Fig. 3b) from about $14 \mathrm{kyr}$ BP onwards (Stage v) in Fig. 4). Extrapolation of kinetic datasets obtained from dolomite formation through $\mathrm{Ca}-\mathrm{Mg}$ carbonate intermediates and estimation of the time needed for the ordering of the dolomite crystal lattice (cf. Eq. $7 \mathrm{in}^{46}$ ) indicate that $\sim 3.0 \pm 0.2 \mathrm{kyr}$ and $\sim 2.8$ to $1.8 \mathrm{kyr}$ are required to form a near-stoichiometric dolomite with a cation ordering ratio of 0.3 at 0 to $3 \pm 6^{\circ} \mathrm{C}$ and 3 to $20 \pm 5^{\circ} \mathrm{C}$ (see Supplementary Table 2 for clumped isotope-based carbonate formation temperatures), respectively, which is consistent with the dark and light brown dolomite-bearing layers at Erzberg. The two dolomite-bearing layers are cross-cut by a youngest aragonite-calcite vein generation, which shows a diffuse transitional zone with partial dolomitization and dolomite overgrowths (see Supplementary Fig. 3 for systematics in carbonate vein mineralizations), indicating that dolomite precipitation has probably continued until recently (Stage vi) in Fig. 4). Hints for ongoing erzbergite formation and dolomitization are provided by a few occurrences of sub-recent aragonite veins $(1.03 \pm 0.04 \mathrm{kyr}$
$\mathrm{BP}^{30}$ ), the modern hydrochemistry at Erzberg promoting aragonite and dolomite formation (see Supplementary Table 3), and (palaeo)-fluid $\delta^{18} \mathrm{O}$ values obtained from erzbergite and matrix dolomite resembling $\delta^{18} \mathrm{O}$ compositions measured for modern fracture and surface water (see Supplementary Table 2).

Special features of continental-meteoric dolomite formation at Erzberg: In contrast to previously published studies on sedimentary dolomite formation in continental-meteoric or marinelacustrine environments at low temperature $20,21,23,25,26,44,47$, we found no evidence for detrital dolomite in the local carbonate host rocks and in the adjacent sedimentary rocks from the catchment areas, demonstrating that the dolomites at Erzberg are authigenic. This argues against the possibility that young faultactivity has pulverized any host rock dolomites and that such reactive (nano-scale) grains could have acted as nuclei for the later (over)growth of the fracture dolomites at a low temperature $^{48}$. On the contrary, a participation of ankerite nuclei in the dolomitization process cannot be completely excluded, because of the structural similarity between the two minerals.

Modern or relict microbial biofilms, laminated crusts, fossilized algae, EPS or bacterial forms have not been identified in the dolomite-bearing layers at Erzberg, which is consistent with the low total organic carbon contents (TOC of $<0.1 \mathrm{wt} . \%$ ) of the carbonate rocks. Similar features were derived from the study of Quaternary speleothem-associated dolomites of the Snežna Jama cave, Slovenia, i.e., no evidence for the participation of microorganisms during dolomite formation was found ${ }^{20}$. However, genetic relations between dolomite crystal growth and microbes have been observed in other karst environments, such as in speleothems of the Cayman Brac and in speleothems of lava tubes of Hawaii ${ }^{20}$. It has been argued that disordered dolomite, that is, mineralogically speaking, a very high-Mg calcite, can abiotically precipitate at ambient temperature from solutions containing polysaccharides, which is readily produced from degrading organic matter ${ }^{49}$. Recently, it was hypothesized that such disordered $\mathrm{Ca}-\mathrm{Mg}$ carbonate precursors could serve as a reactive template to recrystallize to dolomite over time ${ }^{10,14}$. Thus, the involvement of microbes, whether direct or indirect, in the cold fracture system at Erzberg occupied by carbonate minerals that has been active since the last glaciation cannot be completely ruled out.

Arguably low to moderate concentrations of redox-sensitive elements (2100 to $2800 \pm 2200 \mathrm{mg} / \mathrm{kg}$ of $\mathrm{Fe}$ and $\mathrm{Mn}$ ) and the virtual absence of any transition metals in the dolomites from Erzberg indicate that dominantly oxic conditions prevailed during the majority of the crystal growth of the dolomites. This contrasts with the occurrences of modern and ancient dolomites in mostly reducing sedimentary environments and deep-marine dolomites formed alongside anaerobic oxidation of methane, which frequently contain much higher $\mathrm{Fe}$ and $\mathrm{Mn}$ contents (e.g., several mole percent ${ }^{13,50-53}$ ). Moreover, the extremely low Na and $\mathrm{Sr}$ contents $(30 \pm 10 \mathrm{mg} / \mathrm{kg})$ of the dolomites from Erzberg greatly differ from common marine and lacustrine dolomites (e.g., several hundreds of $\mathrm{mg} / \mathrm{kg}^{13}$ ).

Finally, it seems unlikely that the presence of illitic clays or carboxyl functional groups had a strong influence on dolomitization at Erzberg, i.e., through electrostatic binding, desolvation and carbonation of $\mathrm{Mg}^{2+}$ and $\mathrm{Ca}^{2+}$ ions at the fluid-mineral interface ${ }^{16,19}$. This is indicated by the low contents of illite in the carbonate fracture mineralizations and low concentrations of dissolved organic carbon species (DOC: $0.4 \mathrm{mg} / \mathrm{l}$ ) present in the modern meteoric water from southern sections at Erzberg.

It can be concluded that high $\mathrm{Mg} / \mathrm{Ca}$ ratios and carbonate alkalinity, elevated $\mathrm{pH}$, carbonate precursors and reaction time ${ }^{3,8,46}$ are likely the most critical parameters for controlling the formation of the fracture dolomites at Erzberg. Favorable 
physicochemical conditions in the continental-meteoric setting at Erzberg have indeed led to the formation of fracture dolomites that are encountered unique, e.g., see Supplementary Tables 4-8 for mineralogical, elemental, and isotopic signature.

Fracture dolomite as a continental palaeo-environmental archive. The reconstruction of palaeo-environmental conditions recorded in continental and marine carbonate archives is the key to the understanding of the Earth's climatic evolution over time, and for the prediction of the potential responses of terrestrial ecosystems to modern climate change ${ }^{53,54}$. At present, the reconstruction of continental depositional environments of the past and evidence for particularly rapid climate change in modern times are largely derived from the study of speleothems, lake deposits, travertine, fracture carbonates and soil carbonates, i.e., calcrete $^{25,26,36,55,56}$. Our study demonstrates the potential of authigenic carbonates infilling young fractures in the low temperature and high-altitude alpine environment of Erzberg to be used as a sensitive palaeo-environmental archive. Apart from the prominent erzbergite fracture mineralizations, whose applicability in palaeo-environmental reconstruction studies has been recently evaluated ${ }^{30}$, the carbonate fracture mineralizations exposed in the southern section at Erzberg host two generations of authigenic fracture dolomites. Both dolomite generations carry important environmental information on varying palaeo-fluid $\delta^{18} \mathrm{O}$ compositions ( -14.1 to $-8.5 \%$, VSMOW), water flow paths and related crystallization modes (phreatic vs. vadose), palaeo-redox conditions (dominantly oxic), dolomite depositional ages (Pleistocene to recent) and formation temperatures (glacial to ambient interglacial), which have not yet been been reported in dolomite research.

Complementary analyses of radiogenic $\mathrm{Sr}\left({ }^{87} \mathrm{Sr} /{ }^{86} \mathrm{Sr}\right)$ isotopic compositions of the erzbergite, dolomite-bearing layers, carbonate host rocks and meteoric water-derived solutions provide additional clues on the provenance of $\mathrm{Sr}$ in the carbonates, the origin of water and fluid-rock interactions $s^{57}$, with implications for the interpretation of modern hydrochemistry at Erzberg. Specifically, from the cross-plot of the ${ }^{87} \mathrm{Sr} /{ }^{86} \mathrm{Sr}$ composition vs. 1/Sr (Fig. 6) the following conclusions can be drawn: (i) The origin of the carbonate fracture mineralizations at Erzberg can be explained by contributions from two sources, with iron ore carbonates and Devonian limestones (Sauberger Kalke) as endmembers. (ii) The ${ }^{87} \mathrm{Sr} /{ }^{86} \mathrm{Sr}$ isotopic composition of the spheroidal dolomite is mainly sourced from the dissolution of the iron ore carbonates, which suggests that intensified weathering and restricted water flow prevailed at around the Last Glacial Maximum (cf. Stage iv) in Fig. 4). (iii) Erzbergite and matrix dolomite have a mixed ${ }^{87} \mathrm{Sr} /{ }^{86} \mathrm{Sr}$ isotopic composition, indicative of changes in provenance and related water mixing regimes in more recent times (cf. Stage iv) and (v) in Fig. 4). (iv) The modern hydrochemistry at Erzberg still holds a great potential for recent erzbergite formation and even dolomitization, as inferred from the similar ${ }^{87} \mathrm{Sr} /{ }^{86} \mathrm{Sr}$ isotopic compositions of geologically young erzbergite, matrix dolomite and meteoric water from southern sections at Erzberg. Most of the modern fracture water and surface water at Erzberg are strongly oversaturated with respect to aragonite, calcite and dolomite (see Supplementary Table 3 for modern water composition), which suggests that the carbonate vein mineralizations still proceed until recently. The latter findings make this study site interesting for future studies on thermodynamic and isotopic equilibria between modern meteoric water-derived solutions and young $\mathrm{Ca}-\mathrm{Mg}$ carbonates.

Taking the valuable palaeo-environmental and climatic information recorded in the carbonate fracture mineralizations at Erzberg, we call for a change in the long-standing conceptual view that fracture and gangue carbonates formed in continental surroundings are not particularly useful in regional-scale environmental reconstruction studies ${ }^{58,59}$. Considering the vast expanse of cool and high-latitude settings and high-altitude mountain regions worldwide, well known to be particularly sensitive to climate variations, and the extensive occurrence of carbonates therein ${ }^{60,61}$, a critical re-evaluation of the proxy potential of these mineral archives (including the observation of authigenic dolomite) is needed to enlarge both the quality and quantity of currently available carbonate-based continentalsedimentary records. In this line, already known occurrences of speleothem-associated dolomites, for example, in the Titus Canyon Cave (California, USA), the Carlsbad Caverns (New Mexico, USA), the Baruta Cave (Venezuela), the Sumidero Tenejapa Cave (Mexico), the Soreq Cave (Israel), the Cueva de Nerja Cave (Spain), the Castañar Cave (Spain), and the Cayman Brac (UK) (see ref. ${ }^{20}$ and references therein), should be revisited regarding their applicability in palaeo-environmental reconstructions. Furthermore, if one could demonstrate that Quaternary, continental and deep marine, dolomite deposits are more widespread than previously thought, recent uncertainties in the oceanic $\mathrm{Mg}$ budget could be much better constrained: Based on an extensive $\delta^{26} \mathrm{Mg}$ isotope dataset it has been proposed that a significant, yet undetermined, dolomitic sink should exist ever since the Neogene ${ }^{62}$. Our study results demonstrate dolomite formation via Ca-carbonate precursors at cool to ambient Earth surface temperatures within a geologically short timeframe, which is consistent with the sub-recent dolomite formation in deepmarine basins proposed recently ${ }^{62}$. It is up to future studies to quantify the fluxes of $\mathrm{Mg}$ linked to the formation of dolomite and its precursors in different continental and marine sedimentary basins and to estimate the relative contribution of such environments to the global Mg cycling and budget. We conclude that fracture dolomites precipitating in continental-meteoric settings at low temperature can create unique and environmentally restrictive chemical-sedimentary archives, which should be considered in future climate and environmental studies.

\section{Methods}

Materials. Field work and related collection of oriented, hand-sized specimens of erzbergite, carbonate host rocks (Sauberger Kalk and iron ore carbonates) and dolomite-hosting mineralizations was carried out during several field trips from November 2016 to June 2018. Samples were taken explicitly from the southern section of Erzberg, because the locally more widespread authigenic carbonate fracture mineralizations contain abundant dolomite (for sampling sites see Figs. 1 and 2). The more restricted occurrences of fracture carbonates from the central and northern sections are typically composed exclusively of erzbergite. The authigenic dolomite-hosting layers from this site are of particular interest, because of their continental-meteoric and low temperature origin and the young depositional age, making these carbonate fracture mineralizations interesting as archive for climatic and palaeo-environmental conditions. In addition, modern fracture and surface water from northern, central and southern sections at Erzberg were analyzed for their chemical and isotopic composition (for sampling locations see Fig. 1b). The samples were initially recovered during two field campaigns in July 2015 and April 2016 from nine different places at Erzberg ${ }^{30}$. Access to the different sampling sites across the open pit mine was permitted by DI Hannes M. Pluch (Geologie, Bergbauplanung \& Qualitätssteuerung, VA Erzberg GmbH).

Characterization of modern aqueous solutions. Water temperature, specific electric conductivity and $\mathrm{pH}$ were measured on-site using a WTW Multi350i combi instrument equipped with SenTix41 and TetraCon325 electrodes. Liquid samples were filtered via $0.45 \mu \mathrm{m}$ cellulose acetate membranes. One aliquot per sample was kept untreated, whereas another aliquot was acidified to a $2 \% \mathrm{HNO}_{3}$ matrix for subsequent hydrogeochemical analysis (see below).

Major cations and anions in solution were analyzed by ion chromatography (Dionex ICS-3000; analytical error: $<3 \%$ ). Carbonate alkalinity (expressed as $\mathrm{HCO}_{3}^{-}$) was measured by automatic titration with a $0.02 \mathrm{M} \mathrm{HCl}$ solution (Schott TA20plus titrator; analytical error: $<3 \%)$. Minor and trace elemental concentrations were determined by inductively coupled plasma-optical emission spectrometry (ICP-OES, Optima 8300 DV; analytical error: $<5 \%$ ). The dissolved organic carbon 


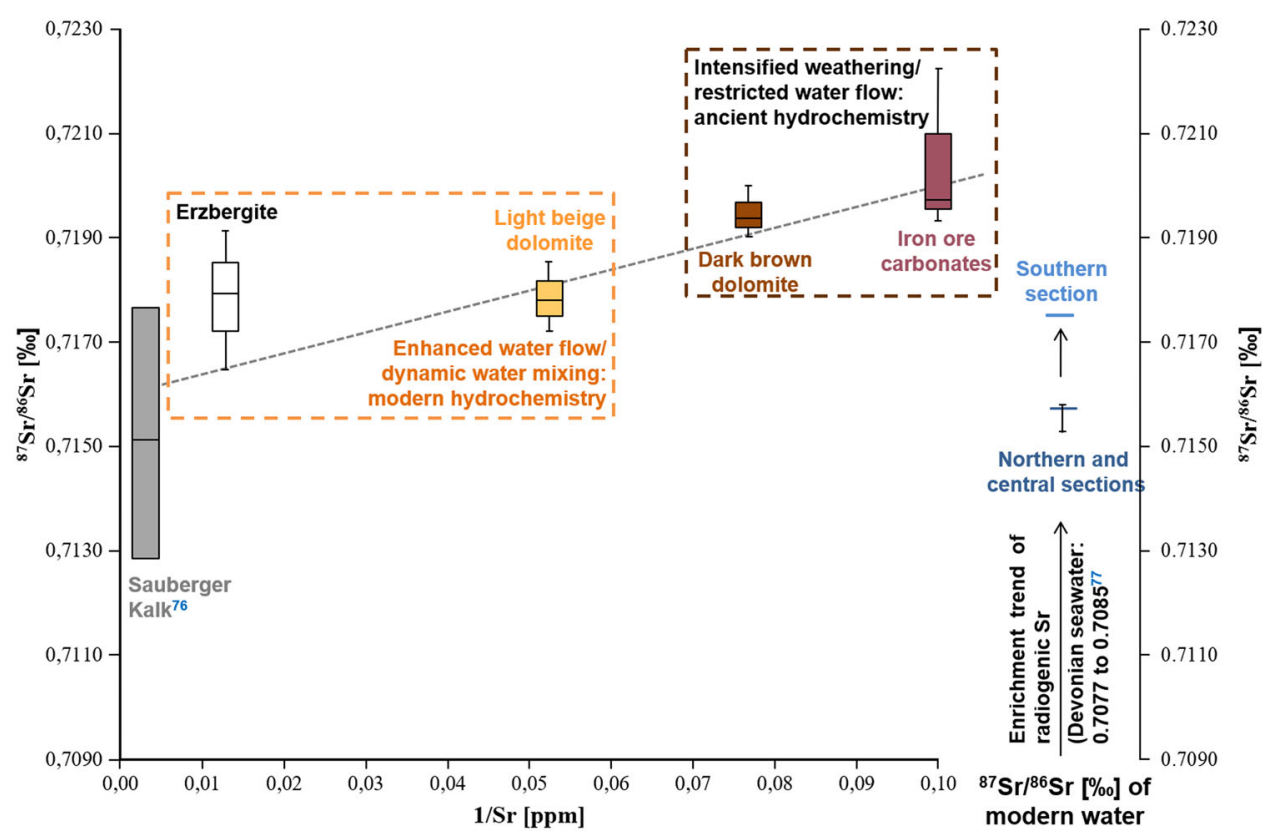

Fig. 6 87Sr/86Sr vs. 1/Sr mixing diagram indicating a mixed origin of the authigenic carbonate fracture mineralizations at Erzberg. The "old and cool" dark brown dolomite spheroids are mainly sourced from dissolution of iron ore carbonates, whereas the "young and warm" light beige dolomite and the erzbergite carbonate have a mixed origin, being strongly affected by the Sauberger Kalk aquifer host rock. Modern water draining the Erzberg (right site), especially from the southern area, are beneficial for (sub-)recent carbonate precipitation and dolomitization. Note that all carbonates have a non-marine ${ }^{87} \mathrm{Sr} /{ }^{86} \mathrm{Sr}$ isotopic signature due to the variable enrichment of radiogenic $\mathrm{Sr}$ during multiple recrystallization events, which are most likely related to the mineralization of the iron ore carbonates. Analytical error is smaller than symbol size unless stated otherwise.

(DOC) concentration was analyzed using a Shimadzu TOC-V-CPH Total Organic Carbon Analyzer (analytical precision: $\pm 0.1 \mathrm{mg} / \mathrm{l}$ ).

Hydrochemical modeling based on the measured water parameters was carried out using the PHREEQ-C computer code with its wateq4f.dat database ${ }^{63}$. This included the calculation of aqueous speciation, ion activities, ionic strength, ion charge balance and saturation indices of the surface and fracture water at Erzberg with respect to calcite, aragonite and dolomite, as well as $\mathrm{CO}_{2}$ partial pressure (internal $\mathrm{pCO}_{2}$ ).

Stable isotope analyses of meteoric water-derived solutions included their hydrogen $\left(\delta^{2} \mathrm{H}\right)$ and oxygen $\left(\delta^{18} \mathrm{O}\right)$ isotopic values, carbon isotopes of dissolved inorganic carbon $\left(\delta^{13} \mathrm{C}_{\mathrm{DIC}}\right)$ and sulfur isotopes of dissolved sulfate $\left(\delta^{34} \mathrm{SSO}_{4}\right)$. The $\delta^{2} \mathrm{H}$ and $\delta^{18} \mathrm{O}$ values of water were analyzed by wavelength-scanned cavity ringdown spectroscopy (WS-CRDS) using a Picarro L1102-i system at JR-AquaConSol $\mathrm{GmbH}$ (Graz, Austria). Water isotope values are reported relative to the Vienna Standard Mean Ocean Water (VSMOW) reference material (analytical precision: $\pm 0.8 \%$ for $\delta^{2} \mathrm{H}$ and $\pm 0.05 \%$ for $\delta^{18} \mathrm{O}$ ). The $\delta^{13} \mathrm{C}_{\text {DIC }}$ compositions were analyzed accordingly and are reported relative to the Vienna Pee-Dee Belemnite (VPDB) reference material (analytical precision: $\pm 0.1 \%$ for $\delta^{13} \mathrm{C}_{\text {DIC }}$ ). Isotope ratios of $\delta^{34} \mathrm{SSO}_{4}$ were analyzed on a Finnigan MAT 253 mass spectrometer coupled to a Thermo Flash 2000 elemental analyzer through a Thermo Finnigan Conflow III interface at the Leibniz-Institute for Baltic Research Warnemünde (Germany). Isotope values are reported relative to the Vienna Canyon Diablo Troilite (VCDT) reference material (analytical precision: $\pm 0.2 \%$ )

The radiogenic $\mathrm{Sr}\left({ }^{87} \mathrm{Sr} /{ }^{86} \mathrm{Sr}\right)$ isotopic composition of selected water samples (six in total) was analyzed with a Plasma II multi-collector inductively coupled plasma mass spectrometer (Nu Instruments, Wrexham, UK; MC-ICP-MS; analytical reproducibility of NIST NBS 987 standard: \pm 0.00001 for ${ }^{87} \mathrm{Sr} /{ }^{86} \mathrm{Sr}$, see Supplementary Table 6) at the NAWI Graz Central Laboratory for Water, Minerals and Rocks, Graz University of Technology (Graz, Austria).

Hydrogeochemical and isotopic compositions of the modern water draining the Erzberg are reported in Supplementary Table 3. An extended discussion of the modern hydrochemistry at Erzberg and a full description of the analytical methods used is provided elsewhere ${ }^{30}$.

Solid-phase characterization. Polished thick sections $(\sim 50 \mu \mathrm{m}$ thick) were prepared from the collected rock specimens to study (i) the mineralogy and petrography of the authigenic carbonate fracture mineralizations as well as (ii) possible indications of post-depositional alteration, such as recrystallization of aragonite and dolomite (over)growth features, by optical microscopy using a Leica DMLP Polarizing Microscope connected to an Olympus DP26 camera.

Rietveld-based analyses of powder X-ray diffraction (XRD) patterns (PANalytical X'Pert PRO diffractometer equipped with a Co-Ka X-ray radiation source and a Scientific X'Celerator detector) obtained from bulk rock samples (cf. Fig. 2a) were made for mineral identification and quantification using the
PANalytical HighScore Plus software package and pdf-4 database (analytical error: $<3 \mathrm{wt} . \%$ for all mineral phases, see Supplementary Table 5). The measuring conditions were as follows: $40 \mathrm{kV}, 40 \mathrm{~mA}$, range: $4-85^{\circ} 2 \Theta$, step size: $0.008^{\circ} 2 \Theta$ and count time: $40 \mathrm{~s}$ per step. Dolomite stoichiometry was calculated from the XRD patterns using the linear expression: $\mathrm{mol} \% \mathrm{CaCO}_{3}=333.33 \cdot d_{(104)}-911.99^{64}$. Therefore, the position of the $\mathrm{d}_{(104)}$-reflection of dolomite was fixed to the position of the main two quartz reflections (analytical error: $<0.6 \mathrm{~mol} \% \mathrm{CaCO}_{3}$ ). The cation ordering ratio in dolomite was calculated from the intensity ratio of the $d_{(015)} / d_{(110)}$ peaks. This approach is semi-quantitative and its accuracy depends on particle orientation and size (analytical precision: $\pm 5 \%)^{52}$.

The rock textures, microfabrics, and geochemical compositions of the erzbergite and dolomite-hosting layers from Erzberg were obtained on polished thick sections by electron microprobe analyses (EMPA) conducted on a JEOL JXA8530F Plus Hyper Probe (JEOL, Tokyo, Japan) at Karl-Franzens-University Graz. Element distribution maps of $1024 \times 1024$ pixel resolution were acquired using a focused beam, $15 \mathrm{keV}$ accelerating voltage, $30 \mathrm{nA}$ beam current and a dwell time of $12 \mathrm{~ms} /$ step. For the single spot analyses of the geochemical composition of the carbonates the analytical conditions were as follows: $15 \mathrm{keV}$ accelerating voltage, $0.5-3.0 \mathrm{nA}$ beam current and defocused beam, $\sim 1.0-3.0 \mu \mathrm{m}$ in size. The quantitative chemical analyses were standardized against natural and synthetic crystals, and included the following elements with characteristic spectral lines: $\mathrm{Ca}-\mathrm{Ka}$ and $\mathrm{Mg}-\mathrm{Ka}$ (dolomite), $\mathrm{Fe}-\mathrm{Ka}$ (siderite), $\mathrm{Mn}-\mathrm{Ka}$ (rhodochrosite) and $\mathrm{Sr}-\mathrm{L} \alpha$ (celestine). Counting times of $20-40 \mathrm{~s}$ on peak and $10-20 \mathrm{~s}$ on the background position on each side of the $\mathrm{Ca}$, $\mathrm{Mg}, \mathrm{Fe}, \mathrm{Mn}$, and $\mathrm{Sr}$ peaks were used. Only compositions with an analytical error of $\pm 3 \%$ were included into the further consideration (see Supplementary Table 8).

Note here that the $\mathrm{Na}$ and $\mathrm{Sr}$ contents of the authigenic fracture carbonates from Erzberg were obtained by inductively coupled plasma optical emission spectroscopy (PerkinElmer Optima 8300) on acid-digested bulk rock samples $(6 \%$ $\mathrm{HNO}_{3}$ matrix, ultrasonic treatment at $70{ }^{\circ} \mathrm{C}$ for 12 hours). The estimated analytical error is better than $\pm 3 \%$ ( $2 \mathrm{SD}, n=3$ ) for the $\mathrm{Na}$ and $\mathrm{Sr}$ analyses.

The total organic carbon (TOC) content of the carbonates was measured on a Shimadzu TOC-VcPH+ASI-V Total Organic Carbon Analyzer at an analytical error of $\pm 3 \%$.

For ${ }^{238} \mathrm{U}-234 \mathrm{U}-{ }^{230} \mathrm{Th}$ isotopic analyses, small sample specimens (few tens of milligrams of powder) were milled along selected aragonite (erzbergite) growth layers with a tungsten-carbide handheld drill. Subsamples were selected from positions dependent on the anticipated degree of detrital mineral contamination (identified by coloring) or diagenetic alteration (aragonite-to-calcite transition), i.e., all the selected subsamples consist of pure, snow-white aragonite (cf. Fig. 2). Pure dolomite subsamples were not extracted, because abundant $\mathrm{Fe}$-(oxy)hydrates and potential aragonite contents can cause large uncertainties and shifts in the conventional U/Th age determination. Moreover, application of the $\mathrm{U} / \mathrm{Pb}$ small scale isochron dating method by laser ablation-sector field-ICP-MS ${ }^{15}$ to our samples is erroneous, making it impossible to precisely date dolomite phases. After 
acid digestion of the selected erzbergite subsamples using nitric acid and the addition of a ${ }^{229} \mathrm{Th}-{ }^{233} \mathrm{U}-{ }^{236} \mathrm{U}$ tracer (spike), $\mathrm{U}$ and Th aliquots were separated and purified from the carbonate matrix after applying iron co-precipitation and anion-exchange chromatography. This wet-chemical operating procedure is accommodated in a clean laboratory environment ${ }^{65}$. Routinely, chemical yields can reach $\sim 90 \%$ or better for both the $\mathrm{U}$ and $\mathrm{Th}$ fractions. The $\mathrm{U}$ and $\mathrm{Th}$ isotope ratios relevant for the radiometric age determinations were measured via a ThermoFisher Scientific Neptune Plus MC-ICP-MS at the Earth Observatory of Singapore, Nanyang Technological University ${ }^{66}$. Sample solutions were introduced to the instrument via a desolvating nebulizer. Apart from relatively abundant ${ }^{238} \mathrm{U}$ and ${ }^{232} \mathrm{Th}$ measured by Faraday collectors, the different $\mathrm{U}$ and Th isotopes were analyzed in peak-jumping mode applying a secondary electron multiplier installed after a retarding potential quadrupole lens, i.e., an energy filter to improve abundance sensitivity. The mass spectrometric data yielded ${ }^{238} \mathrm{U}$ concentrations from 102 to $1379 \mathrm{ng} / \mathrm{g}$ (mean $753 \mathrm{ng} / \mathrm{g}$ ), i.e., a broad range of intermediate to high $\mathrm{U}$ contents favorable for precise age constraints. Likewise, the analyzed ${ }^{232} \mathrm{Th}$ concentrations ranged from 360 to $13309 \mathrm{pg} / \mathrm{g}$ and, therefore, a relatively large range of ${ }^{230} \mathrm{Th} / 232 \mathrm{Th}$ atomic ratios, from 65 to $4032\left(\times 10^{-6}\right)$, was measured. Absolute U-Th ages were calculated using published ${ }^{234} \mathrm{U}$ and ${ }^{230} \mathrm{Th}$ decay constants ${ }^{67}$ and all the ages were corrected using a bulk Earth ${ }^{230} \mathrm{Th} /{ }^{232} \mathrm{Th}$ atomic ratio of $4.4 \pm 2.2 \mathrm{mg} / \mathrm{kg}$. In the vast majority of the samples analyzed, the influence of the initial Th correction was of minor relevance (cf. Supplementary Table 1, uncorr. vs. corr. ages). The measured isotope ratios and resulting age uncertainties are reported at the $2 \sigma$-level. Typical relative age errors of the Ca-carbonate precipitates range between 0.4 and $1 \%$. Hence, absolute age uncertainties range from decades to few hundreds of years, indicative of U-Th ages of high precision. Finally, the age data were referenced to "years Before Present" (yr BP), where the present is defined as the year 1950 A.D.

Stable $\mathrm{O}$ and $\mathrm{C}$ isotope compositions of the carbonate fracture mineralizations as well as of the carbonate host rocks were obtained from powdered subsamples ( 0.3 to $0.6 \mathrm{mg}$; handheld drill) by continuous-flow isotope-ratio mass spectrometry (ThermoFisher Scientific GasBench II connected to a Finnigan Deltaplus XP spectrometer) in the laboratory facilities of the JR-AquaConSol GmbH (Graz, Austria). Isotope ratios are reported relative to the Vienna Pee-Dee Belemnite (VPDB) reference material (analytical precision: $\pm 0.1 \%$ for $\delta^{13} \mathrm{C}$ and $\pm 0.08 \%$ for $\delta^{18} \mathrm{O}$, see Supplementary Table 7).

The ${ }^{87} \mathrm{Sr} /{ }^{86} \mathrm{Sr}$ isotopic compositions of the carbonate fracture mineralizations and host rocks were measured on a Plasma II MC-ICP-MS at the NAWI Graz Central Laboratory for Water, Minerals and Rocks, Graz University of Technology (Graz, Austria) at an analytical precision of $0.00001 \%$ for ${ }^{87} \mathrm{Sr} /{ }^{86} \mathrm{Sr}$, NBS 987 (see Supplementary Table 6).

Samples for clumped isotope analyses were obtained following the procedure described above for the U/Th age determinations, i.e., pure, snow-white aragonite was drilled with a tungsten-carbide handheld drill. In addition, areas containing pure dolomite were drilled to obtain a few milligrams of sample powder. The mineralogy of the powders was investigated by XRD, which yielded almost pure samples, i.e., aragonite samples free of dolomite, as well as dolomite samples containing less than $1 \%$ of aragonite by weight. Formation temperatures of the carbonate fracture mineralizations were then derived from clumped isotope (i.e., multiply-substituted isotopologues; $\Delta_{47}$-values) analyses performed on ThermoFisher 253 Plus stable isotope-ratio mass spectrometers at ETH Zurich (Switzerland) and Heidelberg University (Germany). At Heidelberg University, all samples were processed on a manual line, reacted with phosphoric acid at $90^{\circ} \mathrm{C}$ for $10 \mathrm{~min}$ and subsequently cleaned through a Porapak trap ${ }^{68}$. Typical measurements consisted of eight acquisitions with ten cycles per sample acquisition. The empirical transfer function (ETF) to project the samples in the carbon dioxide equilibration scale $\left(\mathrm{CDES}^{69}\right)$ was determined utilyzing a combination of equilibrated gases and internal carbonate standards. The data from Heidelberg are presented for a reaction temperature of $90^{\circ} \mathrm{C}$. Standard deviations (SD) of the analyzed samples are $0.007-0.019 \%$. At ETH Zurich, $100-120 \mu \mathrm{g}$ aliquots of the dolomite samples were reacted in a Kiel device with phosphoric acid at $70{ }^{\circ} \mathrm{C}$, cleaned by transfer through a Porapak trap held at $-40^{\circ} \mathrm{C}$ and analyzed in LIDI mode with $400 \mathrm{~s}$ integration ${ }^{70}$. All data are presented in the CDES for a reaction temperature of $70^{\circ} \mathrm{C}$ and were calculated with the IUPAC parameters and the revised values of the ETH standards used for normalization ${ }^{71}$ using the software "Easotope"72. Carbonate precipitation temperatures (see Supplementary Table 2) were calculated for dolomite with published $\Delta_{47}$-T relationships for samples reacted at $90{ }^{\circ} \mathrm{C}$ (Heidelberg University $)^{28}$ and at $70^{\circ} \mathrm{C}$ (ETH Zurich $)^{73}$. The use of calibrations that were determined at exactly the same temperature and same procedures during acid reaction avoids uncertainties due to acid fractionation corrections. For aragonite, we applied $\Delta_{47}$-T relationships published elsewhere ${ }^{74}$, consistent with previous approaches on erzbergite formations at Erzberg ${ }^{30}$.

A full description of the analytical methods used is provided elsewhere ${ }^{30,52}$. A summary of the mineralogical, geochemical, and isotopic compositions of the authigenic carbonate fracture mineralizations, as well as of the local carbonate host rocks at Erzberg is reported in Supplementary Table 4.

\section{Data availability}

Raw data are provided in the Supplementary Information of this article, and are available in the Zenodo repository, https://zenodo.org/record/4061740\#.X3W_qu2xU-U.
Received: 4 June 2020; Accepted: 2 October 2020;

Published online: 21 October 2020

\section{References}

1. Budd, D. A. Cenozoic dolomites of carbonate islands: their attributes and origin. Earth Sci. Rev. 42, 1-47 (1997).

2. Burns, S. J., McKenzie, J. A. \& Vasconcelos, C. Dolomite formation and biogeochemical cycles in the Phanerozoic. Sedimentology 47(Suppl. 1), 49-61 (2000).

3. Warren, J. Dolomite: occurrence, evolution and economically important associations. Earth Sci. Rev. 52, 1-81 (2000).

4. Kaczmarek, S. E. \& Thornton, B. P. The effect of temperature on stoichiometry, cation ordering, and reaction rate in high-temperature dolomitization experiments. Chem. Geol. 468, 32-41 (2017).

5. Murray, S. T. \& Swart, P. K. Evaluating formation fluid models and calibrations using clumped isotope paleothermometry on Bahamian dolomites. Geochim. Cosmochim. Acta 206, 73-93 (2017).

6. Petrash, D. A. et al. Microbially catalyzed dolomite formation: from nearsurface to burial. Earth-Sci. Rev. 171, 558-582 (2017).

7. Land, L. S. Failure to precipitate dolomite at $25^{\circ} \mathrm{C}$ from dilute solution despite 1000-fold oversaturation after 32 years. Aquat. Geochem. 4, 361-368 (1998).

8. Gregg, J. M., Bish, D. L., Kaczmarek, S. E. \& Machel, H. G. Mineralogy, nucleation and growth of dolomite in the laboratory and sedimentary environment: a review. Sedimentology 62, 1749-1769 (2015).

9. Chang, B. et al. Massive formation of early diagentic dolomite in the Ediacaran ocean: Constraints on the "dolomite problem". Proc. Natl Acad. Sci. USA 117, 14005-14014 (2020)

10. Pina, C. M., Pimentel, C. \& Crespo, A. Dolomite cation order in the geological record. Chem. Geol. 547, 119667 (2020).

11. Arvidson, R. S. \& MacKenzie, F. T. The dolomite problem: control of precipitation kinetics by temperature and saturation state. Am. J. Sci. 299, 257-288 (1999).

12. Bontognali, T. R. R., McKenzie, J. A., Warthmann, R. J. \& Vasconcelos, C. Microbially influenced formation of Mg-calcite and Ca-dolomite in the presence of exopolymeric substances produced by sulphates-reducing bacteria. Terra Nova 26, 72-77 (2014).

13. Swart, P. K. The geochemistry of carbonate diagenesis: The past, present and future. Sedimentology 62, 1233-1304 (2015).

14. Kaczmarek, S. E., Gregg, J. M., Bish, D. L., Machel, H. G. \& Fouke, B. W. in Characterization and Modeling of Carbonates-Mountjoy Symposium 1 (eds MacNeil, A., Lonnee, J. \& Wood, R.) Vol. 109, 7-20 (SEPM Special Publication, 2017).

15. Mueller, M. et al Testing the preservation potential of early diagenetic dolomites as geochemical archives. Sedimentology, https://doi.org/10.1111/ sed.12664 (2019).

16. Roberts, J. A. et al. Surface chemistry allows for abiotic precipitation of dolomite at low temperature. Proc. Natl Acad. Sci. USA 110, 14540-14545 (2013).

17. Petrash, D. A. et al. Can Mn-S redox cycling drive sedimentary dolomite formation? A hypothesis. Chem. Geol. 404, 27-40 (2015).

18. Wang, Z., Huang, K., Zhang, D., Liu, X. \& Luo, W. Maturation of Neogene dolomite from Xuande Atoll of Xisha archipelago, the South China Sea. Mar. Petrol. Geol. 92, 51-64 (2018).

19. Liu, D. et al. Experimental evidence for abiotic formation of low-temperature proto-dolomite facilitated by clay minerals. Geochim. Cosmochim. Acta 247, 83-95 (2019).

20. Martín-Pérez, A., Košir, A. \& Otoničar, B. Dolomite in speleothems of Snežna Jama Cave, Slovenia. Acta Carsologica 44, 81-100 (2015).

21. Bustillo, M. A., Arribas, M. E. \& Bustillo, M. Dolomitization and silicification in low-energy lacustrine carbonates (Paleogene, Madrid Basin, Spain). Sed. Geol. 151, 107-126 (2002).

22. Van de Velde, J. H., Bowen, G. J., Passey, B. H. \& Bowen, B. B. Climatic and diagenetic signals in the stable isotope geochemistry of dolomitic paleosols spanning the Paleocene-Eocene boundary. Geochim. Cosmochim. Acta 109, 254-267 (2013).

23. Mather, C. C., Skrzypek, G., Dogramaci, S. \& Grierson, P. F. Paleoenvironmental and paleohydrochemical conditions of dolomite formation within a saline wetland in arid northwest Australia. Quat. Sci. Rev. 185, 172-188 (2018).

24. Suarez, M. B., Ludvigson, G. A., González, L. A. \& You, H.-L. Continental paleotemperatures from early Cretaceous dolomitic lake, Gansu province, China. J. Sed. Res. 87, 486-499 (2017).

25. McCormack, J., Bontognali, T. R. R., Immenhauser, A. \& Kwiecien, O. Controls on cyclic formation of quaternary early diagenetic dolomite. Geophys. Res. Lett. 45, 3625-3634 (2018). 
26. De Boever, E., Brasier, A. T., Foubert, A. \& Kele, S. What do we really know about early diagenesis of non-marine carbonates?. Sediment. Geol. 361, 25-51 (2017).

27. Winkelstern, I. Z., Kaczmarek, S. E., Lohmann, K. C. \& Humphrey, J. D. Calibration of dolomite clumped isotope thermometry. Chem. Geol. 443, 32-38 (2016).

28. Bonifacie, M. et al. Calibration of the dolomite clumped isotope thermometer from 25 to $350^{\circ} \mathrm{C}$, and implications for a universal calibration for all $(\mathrm{Ca}, \mathrm{Mg}$, $\mathrm{Fe}) \mathrm{CO}_{3}$ carbonates. Geochim. Cosmochim. Acta 200, 255-279 (2017).

29. Ryb, U. \& Eiler, J. M. Oxygen isotope composition of the Phanerozoic ocean and a possible solution to the dolomite problem. Proc. Natl Acad. Sci. USA 115, 6602-6607 (2018).

30. Boch, R. et al. Aragonite-calcite veins of the 'Erzberg' iron ore deposit (Austria): Environmental implications from young fractures. Sedimentology 66, 604-635 (2019).

31. Prochaska, W. Siderite and magnesite mineralizations in Palaeozoic strata of the Eastern Alps (Austria). J. Alpine Geol. 54, 309-322 (2012).

32. Prochaska, W. Genetic concepts on the formation of the Austrian magnesite and siderite mineralizations in the Eastern Alps of Austria. Geol. Croatica 69, 31-38 (2016)

33. Luetscher, M. et al. North Atlantic storm track changes during the Last Glacial Maximum recorded by Alpine speleothems. Nat. Commun. 6, 6344 (2015).

34. Henjes-Kunst, F., Prochaska, W., Niedermayr, A., Sullivan, N. \& Baxter, E. Sm-Nd dating of hydrothermal carbonate formation: an example from the Breitenau magnesite deposit (Styria, Austria). Chem. Geol. 387, 184-201 (2014).

35. Žák, K., Onac, B. P. \& Perşoiu, A. Cryogenic carbonates in cave environments: A review. Quat. Int. 187, 84-96 (2008).

36. Spötl, C., Fohlmeister, J., Cheng, H. \& Boch, R. Modern aragonite formation at near-freezing conditions in an alpine cave, Carnic Alps, Austria. Chem. Geol. 435, 60-70 (2016).

37. Bischoff, J. L. Kinetics of calcite nucleation: Magnesium ion inhibition and ionic strength catalysis. J. Geophys. Res. 73, 3315-3322 (1968).

38. Berner, R. A. The role of magnesium in the crystal growth of calcite and aragonite from sea water. Geochim. Cosmochim. Acta 39, 489-494 (1975).

39. Gutjahr, A., Dabringhaus, H. \& Lacmann, R. Studies of the growth and dissolution kinetics of the $\mathrm{CaCO}_{3}$ polymorphs calcite and aragonite II. The influence of divalent cation additives on the growth and dissolution rates. $J$ Cryst. Growth 158, 310-315 (1996).

40. Purgstaller, B., Dietzel, M., Baldermann, A. \& Mavromatis, V. Control of temperature and aqueous $\mathrm{Mg}^{2+} / \mathrm{Ca}^{2+}$ ratio on the (trans-)formation of ikaite. Geochim. Cosmochim. Acta 217, 128-143 (2017).

41. Chen, S. et al. Mechanism of solid-state clumped isotope reordering in carbonate minerals from aragonite heating experiments. Geochim. Cosmochim. Acta 258, 156-173 (2019).

42. Guo, Y., Deng, W. \& Wei, G. Kinetic effects during the experimental transition of aragonite to calcite in aqueous solution: insights from clumped and oxygen isotope signatures. Geochim. Cosmochim. Acta 248, 210-230 (2019).

43. Dietzel, M., Purgstaller, B., Kluge, T., Leis, A. \& Mavromatis, V. Oxygen and clumped isotope fractionation during theformation of $\mathrm{Mg}$ calcite via an amorphous precursor. Geochim. Cosmochim. Acta 276, 258-273 (2020).

44. Alonso-Zarza, A. M. \& Martín-Pérez, A. Dolomite in caves: Recent dolomite formation in oxic, non-sulfate environments. Castañar Cave, Spain. Sediment. Geol. 205, 160-164 (2008).

45. Khalaf, F. I. Occurrence of phreatic dolocrete within tertiary clastic deposits of Kuwait, Arabian Gulf. Sediment. Geol. 68, 223-239 (1990).

46. Kell-Duivestein, I. J., Baldermann, A., Mavromatis, V. \& Dietzel, M. Experimental formation of dolomite and magnesite-control of temperature, alkalinity and calcium carbonate reactant. Chem. Geol. 529, 119292 (2019).

47. Ding, Y. et al Cavity-filling dolomite speleothems and submarine cements in the Ediacaran Dengying microbialites, South China: Responses to highfrequency sea-level fluctuations in an 'aragonite-dolomite sea'. Sedimentology, https://doi.org/10.1111/sed.12605 (2019).

48. Siman-Tova, S., Affek, H. P., Matthews, A., Aharonov, E. \& Reches, Z. Shear heating and clumped isotope reordering in carbonate faults. Earth Planet. Sci. Lett. 445, 136-145 (2016).

49. Zhang, F., Xu, H., Konishi, H., Shelobolina, E. S. \& Roden, E. E. Polysaccharide-catalyzed nucleation and growth of disordered dolomite: a potential precursor of sedimentary dolomite. Am. Miner. 97, 556-567 (2012).

50. Taylor, T. R. \& Sibley, D. F. Petrographic and geochemical characteristics of dolomite types and the origin of ferroan dolomite in the Trenton Formation, Ordovician, Michigan Basin, U.S.A. Sedimentology 33, 61-86 (1986).

51. Meister, P. et al. Dolomite formation within the methanogenic zone induced by tectonically driven fluids in the Peru accretionary prism. Geology 39, 563-566 (2011).
52. Baldermann, A. et al. The role of bacterial sulfate reduction during dolomite precipitation: Implications from Upper Jurassic platform carbonates. Chem. Geol. 412, 1-14 (2015).

53. Laudon, H. et al. Save northern high-latitude catchments. Nat. Geosci. 10, 324-325 (2017).

54. Lehnherr, I. et al. The world's largest High Arctic lake responds rapidly to climate warming. Nat. Commun. 9, 1290 (2018).

55. Swanson, E. M., Wernicke, B. P., Eiler, J. M. \& Losh, S. Temperatures and fluids on faults based on carbonate clumped-isotope thermometry. Am. J. Sci. 312, 1-21 (2012).

56. Richoz, S. et al. Geochemistry and mineralogy of the Oligo-Miocene sediment of the Valley of Lakes, Mongolia. Palaeobio. Palaeoenv. 97, 233-258 (2017).

57. Kovács, Z. et al. New constraints on the evolution of ${ }^{87} \mathrm{Sr} /{ }^{86} \mathrm{Sr}$ of seawater during the Upper Triassic. Global Planet. Change 192, 103255 (2020).

58. Pagel, M. et al. Improving paleohydrological and diagenetic reconstructions in calcite veins and breccia of a sedimentary basin by combining $\Delta_{47}$ temperature, $\delta^{18} \mathrm{O}$ water and U-Pb age. Chem. Geol. 481, 1-17 (2018).

59. Swanson, E. M., Wernicke, B. P. \& Eiler, J. M. Fluid flow, brecciation, and shear heating on faults: Insights from carbonate clumped-isotope thermometry. Tectonics 37, 2938-2960 (2018).

60. Burgener, L. K. et al. Clumped isotope constraints on equilibrium carbonate formation and kinetic isotope effects in freezing soils. Geochim. Cosmochim. Acta 235, 402-430 (2018).

61. Staudigel, P. T. et al. Cryogenic brines as diagenetic fluids: reconstructing the diagenetic history of the Victoria Land Basin using clumped isotopes. Geochim. Cosmochim. Acta 224, 154-170 (2018).

62. Shalev, N., Bontognali, T. R. R., Wheat, C. G. \& Vance, D. New isotope constraints on the $\mathrm{Mg}$ oceanic budget point to cryptic modern dolomite formation. Nat. Commun. 10, 5646 (2019).

63. Parkhurst, D. L. \& Appelo, C. A. J. User's Guide to PHREEQC (Version 2)-A Computer Program for Speciation, Bath-reaction, One-dimensional Transport, and Inverse Geochemical Calculations. Water-Resources Investigations Report 99-4259 (USGS, Denver CO, USA, 1999).

64. Lumsden, D. N. \& Chimahusky, J. S. Relationship between Dolomite Nonstoichiometry and Carbonate Facies Parameters. In Concepts and Models of Dolomitization, (eds Zenger, D. H., Dunham, J. B. \& Ethington, R. L.) 28, 123-137 (Society of Economic Paleontologists and Mineralogists, Special Publication, 1980)

65. Shen, C.-C. et al. High-precision and high-resolution carbonate ${ }^{230} \mathrm{Th}$ dating by MC-ICP-MS with SEM protocols. Geochim. Cosmochim. Acta 99, 71-86 (2012).

66. Wang, X. et al. Hydroclimate changes across the Amazon lowlands over the past 45,000 years. Nature 541, 204-207 (2017).

67. Cheng, H. et al. Improvements in ${ }^{230} \mathrm{Th}$ dating, ${ }^{230} \mathrm{Th}$ and ${ }^{234} \mathrm{U}$ half-life values, and U-Th isotopic measurements by multi-collector inductively coupled plasma mass spectrometry. Earth Planet. Sci. Lett. 371-372, 82-91 (2013).

68. Weise, A. \& Kluge, T. Isotope exchange rates in dissolved inorganic carbon between $40^{\circ} \mathrm{C}$ and $90^{\circ} \mathrm{C}$. Geochim. Cosmochim. Acta 268, 56-72 (2020).

69. Dennis, K. J., Affek, H. P., Passey, B. H., Schrag, D. P. \& Eiler, J. M. Defining an absolute reference frame for 'clumped' isotope studies of $\left.\mathrm{CO}_{2}\right)$. Geochim. Cosmochim. Acta 75, 7117-7131 (2011).

70. Müller, I. A. et al. Carbonate clumped isotope analyses with the longintegration dual-inlet (LIDI) workflow: scratching at the lower sample weight boundaries. Rapid Commun. Mass Spectrom. 31(12), 1057-1066 (2017).

71. Bernasconi, S. M. et al. Reducing uncertainties in carbonate clumped isotope analysis through consistent carbonate-based standardization. Geochem. Geophys. Geosyst. 19, 2895-2914 (2018).

72. John, C. M. \& Bowen, D. Community software for challenging isotope analysis: First applications of"Easotope" to clumped isotopes. Rap. Commun. Mass Spectrom. 30, 2285-2300 (2016).

73. Müller, I. A. et al. Calibration of the oxygen and clumped isotope thermometers for (proto-)dolomite based on synthetic and natural carbonates. Chem. Geol. 525, 1-17 (2019).

74. Kluge, T., John, C. M., Jourdan, A.-L., Davis, S. \& Crawshaw, J. Laboratory calibration of the calcium carbonate clumped isotope thermometer in the $25-250^{\circ} \mathrm{C}$ temperature range. Geochim. Cosmochim. Acta 157, 213-227 (2015).

\section{Acknowledgements}

We acknowledge $\mathrm{H}$. Pluch from the VA Erzberg $\mathrm{GmbH}$, who provided access to the study site and further assisted us with the on-site collection of solid and aqueous solution samples. P. Meister (University of Vienna), K. Ettinger (University of Graz) and A.-L. Grauel are greatly acknowledged for valuable discussions on dolomite formation at low temperature. Funding of the NAWI Graz Central Laboratory for Water, Minerals and Rocks is highly appreciated through the EFRE-Land Steiermark initiative. 
T.K. acknowledges that the IRMS for clumped isotope analyses at Heidelberg University was funded through grant DFG-INST 35/1270-1. X.W. acknowledges funding support from the National Research Foundation of Singapore (grant no. NRF2017NRFNSFC001-047) and the Earth Observatory of Singapore.

\section{Author contributions}

A.B. wrote the manuscript. A.B., A.Z., M.D., and R.B. provided the hydrogeochemical and mineralogical data. F.M. and C.G. conducted the EMP analyses. S.M.B. and T.K. provided the clumped isotope data. K.L. and X.W. measured the U/Th ages. D.H. provided the $87 \mathrm{Sr} / 86 \mathrm{Sr}$ data, and A.L. measured the $\delta 13 \mathrm{C}$ and $\delta 18 \mathrm{O}$ values. F.M. and R.B. discovered the dolomite. All authors contributed to the writing of the manuscript.

\section{Competing interests}

The authors declare no competing interests.

\section{Additional information}

Supplementary information is available for this paper at https://doi.org/10.1038/s43247020-00040-3.

Correspondence and requests for materials should be addressed to A.B.

\section{Peer review information Primary handling editor: Joe Aslin}

Reprints and permission information is available at http://www.nature.com/reprints

Publisher's note Springer Nature remains neutral with regard to jurisdictional claims in published maps and institutional affiliations.

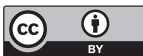

Open Access This article is licensed under a Creative Commons Attribution 4.0 International License, which permits use, sharing, adaptation, distribution and reproduction in any medium or format, as long as you give appropriate credit to the original author(s) and the source, provide a link to the Creative Commons license, and indicate if changes were made. The images or other third party material in this article are included in the article's Creative Commons license, unless indicated otherwise in a credit line to the material. If material is not included in the article's Creative Commons license and your intended use is not permitted by statutory regulation or exceeds the permitted use, you will need to obtain permission directly from the copyright holder. To view a copy of this license, visit http://creativecommons.org/ licenses/by/4.0/.

(C) The Author(s) 2020 